Research Report No. 27/2011

\title{
Transnational Law, Evolving
}

Peer Zumbansen

Osgoode Hall Law School of York University, PZumbansen@osgoode.yorku.ca

Follow this and additional works at: http:/ / digitalcommons.osgoode.yorku.ca/clpe

\section{Recommended Citation}

Zumbansen, Peer, "Transnational Law, Evolving" (2011). Comparative Research in Law \& Political Economy. Research Paper No. 27/ 2011.

http://digitalcommons.osgoode.yorku.ca/clpe/65 


\section{OSGOODE}

OSGOODE HALL LAW SCHOOL

YOR K U N I VERSITY

\section{OSGOODE HALL LAW SCHOOL}

Comparative Research in Law \& Political Economy

RESEARCH PAPER SERIES

Research Paper No. 27/2011

\section{Transnational Law, Evolving}

Peer Zumbansen

\section{Editors:}

Peer Zumbansen (Osgoode Hall Law School, Toronto, Director Comparative Research in Law and Political Economy)

John W. Cioffi (University of California at Riverside)

Leeanne Footman (Osgoode Hall Law School, Toronto, Production Editor)

Comparative Research in Law \& Political Economy 
Osgoode CLPE Research Paper 27/2011

Vol. 07 No. 07 (2011)

Peer Zumbansen

\title{
Transnational Law, Evolving*
}

\begin{abstract}
:
This chapter is the substantively revised and expanded version of the original contribution to the first edition of the Elgar Encyclopedia of Comparative Law (J.Smits, ed., 2006). It reviews and discusses the theoretical scholarship on the concept of transnational law, going back to Philip Jessup's introduction of the term in the nineteen-fifties and tracing it to the present day. The chapter highlights the relevance and potential of the idea of transnational in a range of fields, including commercial law (lex mercatoria), corporate law, international human rights law, comparative constitutional law, anthropology, and 'global administrative law'. The chapter concludes with a number of observations on the growing presence of transnational legal studies in today's law school curricula, in North America and elsewhere.
\end{abstract}

Forthcoming in:

Jan Smits (ed.), Elgar Encyclopedia of Comparative Law (2nd ed., 2012)

\section{Keywords:}

Transnational Law, regulation, corporate governance, legal pluralism, Comparative constitutional law, human rights, legal education

\footnotetext{
* This chapter constitutes the revised version of the 2006 entry in this Encyclopedia. The author is much indebted to friends and colleagues for engaged discussions about the idea of transnational law as methodology, and owes particular gratitude to Alexandra Kemmerer, Fred Aman, Craig Scott, Russell Miller, Neil Walker, Maria Panezi, and Amar Bhatia for continued thought exchange. In the attempt to 'update' the text, the author is conscious of the continuing contentions of transnational law, both as a legal field or, as argued here, a methodology of law. In light also of the fact, that discussions surrounding transnational law have in recent years more fully joined deliberations around 'global governance', 'regulatory capitalism', 'cosmopolitanism' or 'global constitutionalism', the presently amended text will no doubt fall short of adequately identifying and engaging with the immense wealth of evolving theoretical pluralism. In other words, all errors are - of course - still mine.
} 
I.

Positionings. Writing, today, about Transnational Law is a different task from what it was only some years ago (Zumbansen, 2006). Arguably, that would be true when writing about just any field of law, just as it applies to the practice and the teaching of law, which are in constant change: Holmes' remark about the 'remoter and more general aspects of the law' how 'they are those which give it universal interest', and that '[i]t is through them that you not only become a great master in your calling, but connect your subject with the universe and catch an echo of the infinite, a glimpse of its unfathomable process, a hint of the universal' (Holmes, 1897, 478), is as much on point today as at the time of his writing. The following chapter is based on the assumption that, similarly to the remarkable way in which Holmes not only crafted his conception of law and legal thought in communication with and response to the intellectual developments of his time, but also carved out the challenges for law in the future (Posner, 1997), transnational law [TL] must be seen in the context of a vibrant interdisciplinary discourse about the status and role of law in an increasingly inchoate, globe-spanning web of regulatory regimes, actors, norms and processes. On the one hand, TL emerges as a series of contemplations about the form of legal regulation with regard to border-crossing transactions and fact patterns transgressing jurisdictional boundaries that involve a mixture of public and private actors and norms. The locus classicus for this line of thought is, of course, Philip Jessup's series of Storrs Lectures at Yale Law School (Jessup, 1956). On the other hand, transnational law continues to evolve as a thought experiment in legal methodology and legal theory. This line of thought is driven, partly, by the myriad forms of regulatory innovation and interaction that illustrate the transformation of political sovereignty and rule making in a larger process of globalization (Held/McGrew, 2003; Twining, 2000; Dunoff/Trachtman, 2009). Seen from that angle, TL is an illustration of law's attempt to reposition itself in exchange with depictions of a globalizing world, as they are offered from disciplines such as political science (Drache/Boyer, 1996; Levi-Faur, 2005; Drezner, 2007), sociology (Meyer/Boli/Thomas/Ramirez, 1997; Sassen, 2000), economics (Rodrik, 2000), geography (Harvey, 2005) or anthropology (Merry, 2012). At the same time it builds on a longstanding inquiry into the role of law in the context of differentiated, modern societies (Luhmann, 1985). From that perspective, then, thinking about law in a transnational dimension, becomes woven into conceptualizations of the nature and role of law in society. Society is now understood as 'world society', that is, as a society which as subject of investigation not only transgresses and deconstructs the confining space of a particular jurisdiction or nation-state (Stichweh, 2008), but also questions the attempt to position society in a bipolar relation vis-à-vis the state (Teubner, 1997; Willke, 1999; Zumbansen, 2008; Teubner, 2010). What follows from these observations, even for a cursory treatment of the subject in the present context, is the recognition that transnational law presents an important opportunity to reflect on law and its connections to ongoing investigations into local and global forms, institutions and processes of governance.

In other words, the here presented contention is that transnational law invites a fundamental reflection on what is to be considered law. As a term situated between a identification and demarcation of a 'new' field (such as, once, environmental law or, cyber law) and the evolution of related fields (such as private international, or comparative law: 
Miller/Zumbansen, 2012), TL prompts a number of positioning to occur in order to realize its potential. Much in TL turns on the relationship between law and the state, or society in a more comprehensive sense. While Western legal thought has over a considerable time span learned to associate law with the state (Weber, 1967), it is by omission and a narrowing of one's gaze, that this nexus came to be universalized (Fischer-Lescano/Teubner, 2004; see already Bozeman, 1971, ix). Today's interest in 'law and globalization' (Berman, 2005) should thus be seen as a welcome and most timely return to insights into the legal pluralist nature of law, proposed by legal sociologists and anthropologists already a long time ago (Ehrlich, 1962; Moore, 1973; Arthurs, 1988). Aiming for an understanding of society today through legal lenses, then, might prove productive, as law can be seen as reflecting the changing structure of society (Luhmann, 1985). The crucial step, which can be made at this point, is to perceive of society as one in which many communicative forms and rationalities come together, and thus as a society in which states are but historically and geographically identifiable emanations of political organization (Luhmann, 1995). This opens an important vista on the 'history', the 'histories' and the 'non-history' of the state (Hoffmann, 2008), while it allows us to conceive of society as 'world society' (Luhmann, 1982). Understood in this vein, society - not the state - becomes the backdrop and context for our iterations of law and, by consequence, for all ensuing attempts to engage in any form of comparative law. In this understanding of society, the state does not sit 'on top' of society (or, the market), but is part of society.

II.

Beginnings. The first usage of the term transnational law [TL] continues to be disputed. While scholarship has long focused on the origins of the term, it has eventually become apparent that the real challenge of TL lies in its scope and conceptual aspiration within an interdisciplinary research agenda that addresses the transformation of globalized law. Alongside the domestic-international dichotomy that marked international law for the longest time (Nollkaemper/Nijman, 2007), TL is offered as a supplementing and challenging category. Famously conceptualized in a series of narrational explorations by Philip Jessup at Yale Law School (Jessup, 1956), TL 'breaks the frames' (Teubner, 1997) of traditional thinking about interstate relationships by pointing to the myriad forms of border-crossing relations among state and non-state actors. Now, more than half a century after Jessup's lectures, one is well advised to re-read the slim but nevertheless immensely rich volume. Without many references, Jessup invites his audience to imagine an altogether different conceptual framework. This framework would help to reflect on the dichotomies underlying and informing international law while decisively moving onward to embrace a wider and more adequate view of global human activities.

Jessup writes that he "shall use the term 'transnational law' to include all law which regulates actions or events that transcend national frontiers. Both public and private international law are included, as are other rules which do not wholly fit into such standard categories" (Jessup 1956: 2). When examining the inescapable 'problem' of people 
worldwide whose lives are 'affected by rules', Jessup wastes no time in pointing to the striking contingency by which we attribute the label of 'law' to rules, norms or customs that govern various situations. "As man has developed his needs and his facilities for meeting his needs, the rules become more numerous and more complicated. History, geography, preferences, convenience, and necessity have dictated dispersion of the authority to make the rules men live by" (id., at 8). Jessup complements this brazen exposition of the multitude of norm-producing institutions and actors with an intriguing presentation of three short dramas (separated into two scenes each) that illuminate the parallels between domestic and international constellations, in light of which he argues for a transcending transnational - perspective. While the first scenes of two of the three dramas feature individuals who are caught up in disturbing, doctrinally challenging legal conflicts variously involving divorce or the exercise of membership rights in a stock corporation the complementing, second scenes invoke a very similar problem set on the inter-state level. Set against an ensuing discussion between two art critics, Mr. Orthodox and Mr. Iconoclast, Jessup extrapolates the inseparability of the issues that underlie the allegedly exclusively 'domestic' versus the likewise purely 'international' constellations. The truly subversive thrust of Jessup's vision of TL lies in the parallels that can be recognized between supposedly local, or regional issues in one place and those in another one. "One's idea of what constitutes a 'region' is apt to be artificial and highly subjective. The people in Boston and New York today might quite properly feel that they have a closer identity with the people of India than their grandfathers felt interest with the farmers of Iowa" (Id., at 26). With regard to stockholders, Jessup lets Mr. Iconoclast point out the parallels between purportedly domestic discussions concerning 'shareholder democracy' and those involving increased demands for improved participatory rights in the United Nations and other international organizations.

'It is all there, already then', we might be tempted to say, or is it? For the sake of both accolades and brevity, it must suffice to point to resourceful tributes to the significance of "Transnational Law" (Friedmann/Henkin/Lissitzyn, 1972; Tietje/Brouder/Nowrot, 2006), as well as mention Jessup's clairvoyant treatment of issues that would - much later - still occupy our legal minds. Among those are the problem of the extraterritorial reach of antitrust statutes (Buxbaum, 2004; Buxbaum, 2010) as well as the challenge of jurisdictional boundaries and competences (Michaels, 2004; Knop/Michaels/Riles, 2008; Whytock, 2008). The vivid and critical interest in 'global governance' (Kennedy, 2005; Rittich, 2005; Held, 2007) and 'transnational regulation' (Djelic/Sahlin, 2012) further highlights the changing discursive context in which lawyers themselves push the boundaries of 'post-national' law (Walker, 2010; Krisch, 2010). This context is, on the one hand, reflective of the degree to which investigations into transnational law after Jessup have begun to spread out into different legal fields, both in scholarship as in legal education. On the other hand, this work illustrates how attempts to define and formalize TL have matured in their conscious thematizing of the underlying methodological and conceptual challenges arising from law's embeddedness in a comprehensive, multi- and interdisciplinary discourse. In various fields of legal regulation such as contract (Kester, 1997; Calliess, 2007), tort (Scott, 2001), environmental (Brunnée, 2004) or corporate law (Hopt, 2006; Zumbansen, 2011), there has occurred a remarkable expansion of the outside boundaries of the respective fields. Experts in a particular field now find themselves 
inevitably and unavoidably confronted with a fast-changing regulatory and institutional landscape. Facing the intricacies of an evolving transnational regulatory architecture consisting of both public and private, hybrid norm creation systems, no longer exclusively located on either a domestic or international level, lawyers - in theory and practice - are prompted to engage in methodological introspection. In other words, it becomes a natural part of legal research, case preparation and problem solving to integrate legal solutions, principles and rules from a variety of legal levels and cultures (Wiener, 2007, 2). Boundaries between distinctly perceived legal and political, jurisdictionally and systemically perceived systems begin to blur, while contours of specialized, sectorial and functional regulatory regimes become more accentuated.

From the time where the term "globalization" had not yet entered the lexicon when Jessup delivered his lectures, until the present, TL has gained much in contours and weight, giving a powerful voice to the efforts of positioning the law within contemporary struggles to adequately theorize the dispersed and fragmented spaces of norm-production (FischerLescano/Teubner, 2004; Merry, 2006). If Jessup's crucial hint in thinking about the gap left by both public international law and conflict of laws, was to make us think in a new way about the connections between both realms of legal imagination, its relevance today appears to be in prompting the question, what is at stake for a legal theory that attempts to bridge the national and international? Seen in this light, TL's challenge emerges as a reminder of the very fragility and unattainedness of law - both 'inside' and 'outside' the nation state (Zumbansen, 2008). This is why contemporary thinkers place such emphasis on the contested nature of constituencies and communities (Cotterrell, 2008), on accountability (Kingsbury/Krisch/Stewart, 2005) and legitimacy (Kreide, 2009). At the beginning of the $21^{\text {st }}$ Century, we are still at a loss to identify a theory of law that would be subtle enough not to stifle emerging identities in a post-colonial era (Anghie, 2005) while providing forms, fora and processes (Wiethölter, 1986) for the collision of discourses that mark post-metaphysical legal thinking (Habermas, 1996). Jessup had hinted at the need for a comprehensive theory of an emerging 'international society' in his work, and these questions continue to preoccupy scholars in their efforts to address and, perhaps, reconcile the force of disintegrating, atomizing tendencies with increasingly accentuated theories of global constitutionalism and global governance (Tully, 2002; Marks, 2000; Brunkhorst, 2010; Wiener, 2011).

In the term's long history, its variances can be attributed mostly to the different doctrinal and theoretical backgrounds of those employing it. This short exposition of TL will introduce the grand strands of discussion in different branches of legal doctrine and theory by way of visiting and revisiting the places and times of TL in the historical and legal consciousness. Inspired by Philip Jessup's exposition of the idea and concept of TL (Jessup 1956; Schachter, 1986: 878), the remainder of this chapter will address TL from the viewpoint of the commercial (arbitration) lawyer, the corporate, the (comparative) constitutional and administrative lawyer as well as the human rights lawyer and the anthropologist. Finally, the chapter will conclude with brief remarks on the relationship 
between the emerging field of transnational (legal) history and TL as well as on the impact of TL on legal education.

\section{III.}

Lex mercatoria. The rediscovery of the medieval law merchant through the works of commercial lawyers after WWII began a great revival of the notion of a borderless, universal trade law of nations (Goldman, 1964; Schmitthoff, 1964). This notion had received a great deal of attention and intellectual conceptualizing as early as the seventeenth century (Milgrom/North/Weingast, 1990; Stein 1995; Cordes, 2003). As seen above, Jessup proposed that TL should encompass and simultaneously challenge public and private international law, were the latter to maintain their explanatory and guiding potentials in an ever-more integrating world. Commercial lawyers seized this moment and engaged for decades in a far-reaching enterprise of collecting, consolidating, codifying and harmonizing the various laws governing international trade (Schmitthoff, 1961; Goode, 1997; Cranston, 2007). Peculiarly mirroring a more recent dispute of 'fervent imagination' versus the 'school of hard knocks' i.e. visionary, theoretical, perhaps religious, legal thinking as opposed to realist, pragmatic, result-oriented doctrine creation (Thomas Franck, in: Philip Allott Symposium, 16 EJIL 343 [2005]), lawyers carried on with a dispute over both the legal nature and the very existence of lex mercatoria as an autonomous legal order (Schanze, 1986; Stein 1995; Teubner 1997; Mertens, 1997; Berger, 2010; Gaillard, 2010). Aptly characterized as a battle between 'transnationalists' (those embracing the emergence of a self-producing legal order among commercial actors) and 'traditionalists' (emphasizing the continuously important role of the state in enforcing arbitral awards), the dispute over lex mercatoria exposed the vulnerability and burdens of a practice/theorybased challenge to 'official' law, being those state-made norms and statutes embedded in an institutionally sound enforcement environment (Berger, 1996; Calliess, 2002; Zumbansen, 2002).

Two developments, however, have shifted the focus away from such preoccupations. Far from being the products of powerless processes of negotiation, as captured by the phrase of a 'common law of contracts' (Teubner), the autonomous legal order of lex mercatoria could be shown to continue and amplify the power-cleavages between the haves and havenots, between the North and the South, the West and the East (Dezalay/Garth 1995, 1996; Shalakany, 2001; Schneiderman, 2006). In part, this critique premeditated today's understandable scepticism towards what has been coined 'new constitutionalism' (Schneiderman, 2000). However, the proponents of an autonomous legal order are well aware that lex mercatoria will inevitably undergo dramatic phases of repoliticizing (Teubner 1997), by having to meet itself some of the nation states' structural challenges with regulating the economy. This process of repoliticizing forms only one layer of lex mercatoria's coming of age. The concept of TL that underlies and continues to shape the appearance and applicatory scope of lex mercatoria can be seen as unfolding in an even more radical, namely reflexive manner. Much as in Jessup's drama, TL points to the overarching political, perhaps utopian, struggles that are shared among comparable developments and social movements in different 'regions'. The struggle for (legal) recognition of a transnational, de-nationalized lex mercatoria, is the otherwise left behind, 
domestic struggle for the power and legitimacy of order through law. As it is exemplified through lex mercatoria, TL reminds us of the never attained positivity of legal rule, which is a conflict that we have come to address by distinguishing between legality on the one hand, and legitimacy, on the other. TL as a methodology of law, reflexively collapses the boundaries between domestic and international legal (economic, social, cultural, political) problems and, instead, demands to assess the inner connections and resemblances in their alleged differences. These differences are not, however, the result of the opposition between its domestic and international qualities. Rather, the labels of 'domestic' or 'international' are merely the exertions of definitional and conceptual sovereignty over an otherwise untameable power. Dramatically exemplified through the emergence of a denationalized commercial law, TL puts the finger on the very problem of regulatory power and autonomy, of private and public autonomy. In this way, TL reconnects with both 'domestic', private law discussions (over freedom of contract, duress, unconscionability and consumer protection) and the public law themes of deregulation and privatization. These discussions characterize the continuing ideological struggle over the delineation of the state from the market and of the public from the private. Seen against this background, the project of a constitutionalized private law (eg Wiethölter, 1986; Joerges, 2004; Zumbansen, 2007) undertakes the impossible task of sustaining the paradox between these irreducible spheres of societal freedom. This project should not be dismissed solely for lacking the enthusiasm to (re-)embrace a perhaps inadequate conception of the 'state' simply to prevent the market from taking over.

\section{IV.}

Corporations. Administered both centrally and from within inter-firm networks, deterritorialized, globe-spanning company activities bring together a multitude of autonomous organizational and economic actors that easily exhaust the traditional regulatory aspirations of nation states and other political bodies (Hertner, 1998; Herkenrath, 2003). The study of the TL of corporate governance focuses on the various existing regulatory frameworks for business corporations on the domestic, transnational and international level and helps to illuminate the embeddedness of firms in layers of rules (produced by regulatory and self-regulatory bodies), economic and political constraints and historically-evolved legal cultures (Polanyi, 1944; Shonfield, 1965; Granovetter, 1985; Boyer/Hollingsworth, 1997; Zumbansen, 2002b). The embeddedness of business corporations must be understood as relating to their origin and development in systems of production (Storper/Salais, 1997; Jacoby, 2004) as well as in legal and socio-economic cultures. In relation to the regulation of business corporations, TL differentiates between the hard law that governs the corporation through company law (e.g. securities regulation and even labour law) and the soft law of voluntary codes of conduct, corporate governance codes and Human Rights Codes (Backer, 2011). As the latter present a dramatic challenge to traditional understandings of law-making, the analysis of voluntary codes of conduct further illuminates the long acknowledged, complex nature of the regulated and selfregulating firm (Bratton, 2005). Considering the embeddedness of business corporations in 
an increasingly de-nationalized knowledge economy, their placement in a multi-level regulatory field comprised of official and non-official norm-producers becomes more visible. On the one hand, TL comprises the law governing the global business corporation through a multilevel and multi-polar legal regime of hard and soft law, statutes and recommendations, command-control structures of mandatory rules as opposed to an ever more expanding body of self-regulatory rules (Zumbansen, 2002b; Arthurs, 2002). On the other hand, TL functions as a reflexive practice that exposes the tension between the functional differentiation of global markets and the regulatory and legitimizing aspirations of law. The transnational connection between historically and locally acquired learning experiences regarding autonomy, freedom and rights and the pressing concerns regarding participation, representation and legitimacy in world society feeds into the question of how and on what basis lines between official law and non-official law, between hard and soft law, and, ultimately, between law and non-law, are in fact drawn. This realization of falling off the arguably solid ground of the nation state into the abyss of a world without government, democratic rule or constitutionally protected values (Peters, 2009) haunts public and private lawyers alike, as is forcefully illustrated by the intensifying developments in human rights law and comparative constitutional law.

V.

Human Rights Law and Transnational Anthropology. Human rights law has for the longest time been fraught with considerable tension existing between its highflying normative aspirations and its unbounded abstractness. The often cherished history of progress, redemption and alleviation has rightly been called into question (Sen, 1999; Baxi, 2003), giving way to a complex set of often intertwined and contested narratives and approaches towards human rights. Read against the background of an early relativist critique of human rights, ensuing attacks - focusing on gender blindness, structural (e.g. socio-economic) violence or colonial heritage - have helped in creating a discursive climate in which a relatively great number of euphemizing human rights assertions seems to be widely recognized as being out of step with reality and politics. Coalescing through work in international law and international legal history (Koskenniemi, 2002; Anghie, 2005), literary criticism (Said, 1978), cultural theory (Appadurai, 1990), political sociology, (Sousa Santos, 2002) and legal anthropology (Merry, 1992; Riles, 2005), we find an intricate, multi-layered discourse on the concept and the nature of human rights, which suggests a far more differentiated approach to the problems raised by human rights assertion and practice that seems to have been possible in earlier times.

A crucial juncture opens in light of new lines of inquiry, due to the fact that scholars are actively pursuing and identifying sites of cross-disciplinary inquiry and shared concerns. Two developments seem highly promising in that regard: the emergence of the so-called New Legal Realism [NLR] and the increasingly influential field of ethnography of human rights law. The former is coined, in particular, by a progressive interest in making sense of two overlapping and co-evolving developments: one concerns the 'ironic turn' of the legal realist legacy (Zumbansen, 2008), opening - as it were - the gates not only for critical legal studies, critical race theory or 'third world approaches to international law' (Okafor, 2008), 
but also prompt critical engagement with 'law \& economics' (Rittich, 2005, 857: “...both law and economics and critical legal studies are realist progeny.") or 'social norms theory' (McAdams, 1997; Posner, 2000). The other development which NLR is interested in is the dramatic transformation of traditional, state-centred law-making: in response to the far reaching effects of privatization, deregulation and transnationalization of norm-generation, NLR seeks to revive legal sociological and legal pluralist as well as empirical and clinical law approaches to further scrutinize the nature of the emerging normative order (Shaffer/Nourse, 2009). The central gist in this approach is that its proponents pursue both a methodological and a political research program. Seeing how prior assertions of the public nature of private government can easily be converted into a politically opposed policy prescription, NLR scholars demand that we take a closer look at the formal assumptions which inform the recent embrace of societal self-regulation and the primacy of 'norms' over rules (Macaulay, 2000). It becomes obvious that a most important dimension of NLR's approach is an engagement with practice in various forms. One, to be sure, is a renewed interest in empirical legal studies, field work and the concrete study of norms in their regulatory context (Shaffer/Pollack, 2009).

Meanwhile, human rights law has been receiving much critique in the context of its potential cooptation within the law \& development program of the International Financial Institutions, above all the World Bank (Santos, 2006). A particularly powerful contribution to this critique has been mobilized by anthropologists, who have been arguing against unwarranted assumptions regarding the value and the success of human rights norms, criticizing that such assertions often occur without sufficiently taking into account the concrete contextual circumstances (Merry, 2006; Anders, 2008; Sarfaty, 2012). In this vein, human rights lawyers have - in continuation of earlier suggestions (Riles, 2006; Holmes/Marcus, 2005) - emphasized the need and the promise of a more empirically based, field work oriented human rights scholarship (Wilson, 2006; Greenhouse, 2006). Mirroring this commitment, the currently burgeoning literature on this issue is regularly based on extensive field work, which seems to suggest that the wind may be in the sails for the ambitious undertaking to bring human rights law onto the ground of societal practice. The next step to further enhance the practical relevance of this engagement between human rights lawyers and anthropologists will likely be to continue the efforts of further approximating the methodological and normative starting points from which the respective experts embark on their collaboration. The great variances in human rights understandings and the need to expose and explore these potentials for misunderstanding are further exacerbated by the fact that the spaces in which this much-needed collaboration between human rights lawyers and anthropologists themselves constitute highly volatile and treacherous territory. As the human rights/anthropology collaboration often enough occurs in the context of funded development (or, transitional justice) projects there is an even greater need to make both assumptions and expectations explicit and to collectively pursue a continued improvement of the methodological toolkit, with which we may measure the 'success' of human rights development. The recent scrutiny of the World 
Bank's Indicators program is a powerful illustration of the challenges at hand (Merry, 2012).

VI.

Comparative Constitutional Law and Transnational Constitutionalism. Underlying the thriving field of comparative constitutional law is the assumption that we can (still) readily distinguish between 'different systems' and that it is indeed possible to reach even deeper within them in order to assess and interpret recognizable differences in the design, practice and culture of constitutional design. From a transnational law perspective, however, it appears that the foundations on which we can base the identification and demarcation of distinct constitutional systems builds more on historic than on systematic evidence. In light of the increasing 'migration of constitutional ideas' (Choudhry, 2006), processes of 'judicial globalization' (Slaughter, 2000) and an impregnation of constitutional cultures through 'foreign' norms and principles (La Forest, 1996; Arbour/Lafontaine, 2007), it seems that a traditional comparative structure of comparing law approach to the study of distinct legal cultures is no longer satisfying.

The background for today's interest in comparative and transnational constitutionalism is provided by the emergence of a transnational legal-pluralist order (Zumbansen, 2010). This order is characterized by forms of 'legal' regulation, which increasingly encompass a variety of direct and indirect, hard and soft, public and private, domestic or global types of norms, standards, recommendations and guidelines (for examples of transnational contract and corporate law: Calliess/Zumbansen, 2010, ch. 3, ch. 4). As different fields of law are becoming functionally differentiated in that they take on board the particular regulatory dynamics in a given regulatory area, the shapes and forms of legal regulation begin to change as the spaces of regulation break free from traditional, modern state boundaries. For constitutional law, this emerging transnational order underscores the necessity of looking for the constitution 'outside' the constitution (Young, 2007; already Cover, 1983), that is to track constitutional norms in those regulatory structures, where questions of representation, voice and legitimacy are at stake. Comparative constitutional law scholars have begun to embrace such a broader understanding of their field by adopting the term of 'constitutionalism' (Dorsen/Rosenfeld/Sajó/Baer, 2010). Through this lens, a constitutional scholar might recognize the evolution of a transnational culture of constitutionalism, by which is not meant a normative order that emerges autonomously outside of the confines of the nation state and, as such encompasses a distinct space of global governance with no relation to the world of states and the correlating measurements of law, namely national and international. Rather, transnational constitutionalism expresses the continuing evolution of constitutional principles, instruments and doctrines as a particular form of legal evolution today. Transnational constitutionalism radically challenges but does not negate the distinction between the domestic and the international legal order. Again, to reiterate Jessup's emphasis of a transnational legal order, the idea of 'transnational law' can be seen to aptly capture both the emergence of norm creation and enforcement outside of the confines of national/international law, but, now more importantly, outside the confines of established notions of law itself. The latter connects the idea of transnational law with that of legal pluralism, together informing a 
methodological inquiry into the nature of law itself in relation to a theory of society, which is understood as a functionally differentiated world society.

In world society, the reference points for comparative constitutional law begin to lapse both internally within the nation state and beyond its boundaries. The current phase of globalization is marked by a far-reaching transformation in the position and status of states and sovereign political actors, having drastically changed the anchoring and reference points for comparative constitutional studies (Dobner, 2010: 141). From the perspective, then, of the constitution's close association with the state, the prospects of comparative constitutional law seem to be tightly connected to the fate of comparative law in a globalized world, where the contours of statehood have become porous (Kennedy, 1997; Whytock, 2008). Arguably, the relevance of the concept of 'constitutionalism' lies in its potential to build bridges between the constitutional law discourses within the nation state and the investigations into legitimacy of global governance in the 'post-national constellation' (Habermas, 2001; Habermas, 2008).

VII.

Administrative Law. Not only constitutional law, but also administrative law gives strong testimony to the in-between state of TL when reacting to the shifting balance between public administration and private execution, between government and governance (Aman Jr., 1997; Freeman, 2000). After early, unheard recommendations to consider administrative law as a core element of a transnational legal science (Joerges, 1972; Wiethölter, 1977), its recognition as an important field of such a science is of more recent venue (Aman Jr., 2004; Shapiro, 2000). The background is constituted partly by what has been called "regulatory fatigue" (Stewart, 2003), which has otherwise been depicted as the welfare state's increased inability to adequately structure widespread public law and public policy interventions into the social sphere. The promises of a transnational administrative law, in the sense of a widely conceived administrative science as regulatory science (Aman Jr., 2004), particularly lie in the unfolding of a more responsive and experimental approach to public administration (Ladeur, 1997; Vincent-Jones, 2006; Scott, 2008). This approach must be understood in two ways. First, in a procedural sense, transnational administrative law seeks to facilitate processes of participation and deliberation in an otherwise highly dispersed and fragmented public sphere. Second, in a normative sense, it aims at the creation of a regulatory regime that can accommodate public and private claims evolving from privatised and deregulated frameworks of (formerly) public administration (Frankenberg, 1996). TL's focus on norm production connects closely to this two-fold experiment in public administrative theory. Here, TL allows for a parallel view on the allegedly separated spheres of domestic and international legal struggles and posits administrative law as a lens through which to theorize the regulatory regimes of a differentiated world society (Ladeur, 2011). The global arena is populated by a multitude of norm-makers and rule-producers, such as standards and standard-setting organizations. While these entities materialize in widely differing fields, 
their appearance raises familiar, yet new questions with regard to regulatory base and scope as well as legitimacy of grounds and enforcement (Salter, 1999; Brunsson/Jacobsson, 2000; Schepel, 2004; Kingsbury/Krisch/Stewart/Wiener, 2005).

Against this background, the transnational lawyer's attention is today attracted to a still relatively young research enterprise, focusing on 'Global Administrative Law' [GAL] (Kingsbury/Krisch/Stewart, 2005). While, unsurprisingly, this ambitious research project has garnered both enthusiasm and skepticism (Chimni, 2005; Harlow, 2006; Ladeur, 2011), its conceptual and theoretical foundations are still worthy of more exploration. Particularly, where GAL extends its theoretical reach into the global space of regulatory governance in a variety of areas (van Harten, 2006; de Bellis, 2006; Barr/Miller, 2006), the question arises whether and how particular traits of national legal and regulatory cultures can be identified and taken into consideration. In other words, as regards the fast evolving formation of global administrative law concepts, one would like to know to which degree the project is informed by one or more particular contexts of regulatory and doctrinal experiences and if so, what the consequences of this 'background' might be. This query seems even more important as the project's inner struggle with its normative agenda (Krisch, 2009) is directly tied to a concern with the project's inherent biases, as raised by a number of scholars (Chimni, 2005; Marks, 2005). As a research project with a global aspiration, which focuses on insufficiencies in global democratic governance as instantiated by the World Bank, the International Monetary Fund or the World Trade Organization, such a reassessment of its own conceptual and theoretical foundations and histories seems crucial. Otherwise, the project's scholars risk exposing themselves to the critique of approaching global governance questions in the context of the international financial institutions without an awareness of the theoretical, conceptual and political 'baggage' their concepts are in fact coming with. In other words, the question is whether or not a project such as GAL can operate without taking into account the historical-intellectual and political economy contexts in which the central concepts of the project have their origin.

Given the different histories and narratives that inform national understandings of administrative law, with which we embark on any comparison of administrative regimes or, with which we begin to address the regulatory challenges posed by international organizations under the rubric of GAL, we should have a closer look at both the available instruments in comparative law and the subject matter - administrative law - itself. Close readings of national narratives of administrative governance reveal particular connotations of regulatory power and of the relationship between different institutions (legislature, executive, judiciary and administrative agencies) (eg Landis, 1938; Forsthoff, 2000). What emerges of such side-by-side inspections of national narratives, is that particular assessments of administrative governance are based on a particular understanding of the relationship between state and society, between public and private and between citizen and state (Frug, 1983; Grimm, 1980; Stolleis, 2006). Such questions are inseparable from those regarding the role of the state in the market, the definition of property rights or freedom of contract. 
With regard to the ambitious project of conceptualizing a global administrative law, a glance at the legal and intellectual history of governance ideas is likely to reveal a considerable degree of complexity in the respective trajectories of national administrative law traditions. As GAL continues to become more specialized, not least due to the impulses and critique it receives from different sides, prominently for example from critical international law scholarship (Marks, 2005) and the 'Third World Approaches to International Law' scholars (Chimni, 2005; Okafor, 2008), its current lack of interest in national administrative law histories will need to be addressed - sooner rather than later. The still outstanding face-to-face dialogue and reciprocal engagement between the original GAL concept on the one hand, and the 'Public Authority' project under the auspices of the Max Planck Institute for International Law in Heidelberg (Bogdandy/Dann/Goldmann, 2008. Symposium at: http://www.germanlawjournal.com/index.php?pageID=13\&vol=9\&no=11), on the other, is telling in that regard. Meanwhile, some of its most insightful critics have been pointing to the ghosts in the architecture, forcefully bringing to light the problematic tensions between a de-nationalized construction of an administrative governance framework on the one hand and the intricate and concrete histories of this very governance on the ground (Harlow, 2006; Harlow, 1999; Harlow, 2009).

VIII.

Transnational Human Rights Litigation. Beginning in the last two decades of the $20^{\text {th }}$ Century, civil litigation seeking compensation for human rights abuses has occupied courts and - on all fronts - lawyers, academics, practitioners, politicians and journalists around the world (Scott 2001). Inspired by the Filartiga-decision (630 F.2d 876 [1980]), many claims have been brought by former victims of human rights violations against states, state officials and private corporations. The fate of these cases has been - until this very moment in 2011 - mixed at best. While they mostly fail to overcome various existing state immunity thresholds (whereby states and their officials are immune from law suits before courts in foreign states), or are rejected because the courts in question resist hearing cases involving distantly occurred incidents (the so-called forum non conveniens doctrine), plaintiffs and their lawyers do not seem willing to give up their struggle for legal recognition of the wrongdoing (Neuborne, 2002; Stephens, 2002; Keitner, 2008). Recent decisions in U.S. courts keep litigators - and defendants - on their feet, albeit with most unpredictable prospects (Presbyterian Church of Sudan v. Talisman Energy, 582 F.3d 244 (2d Cir. 2009); Kiobel v. Royal Dutch Petroleum, No. 06-4800-cv, 06-4876-cv, 2010 WL 3611392 (2d Cir. Sept. 17, 2010)).

At this juncture, Justice Story's invocation of a law governing commercial transactions and itself being a branch of the 'law of nations' [Swift $v$ Tyson, 41 U.S. (16 Pet) 1 (1842)] meets with the U.S. jurisprudence involving the 1789 Alien Tort Claims Act (28 USC 1350). Reaching back to Cicero (Non erit alia lex Romae, alia Athenis, alia nunc, alia posthac, sed et 
apud omnes gentes, et omni tempore una eademque lex obtinebit) Justice Story, and Lord Mansfield before him, recognized the law merchant as a border-transgressing and genuinely de-nationalized body of law. While subsequent times did see some domestication of this jurisprudence in federalist disguise [Erie R.R. Co. v Tompkins, 304 U.S. 64 (1938)], the frame-breaking character of a transnational law of human rights protection remains a pressing challenge and promise (Scott/Wai 2004). Such a body and practice of law arises against the resistance of jurisdictional and conceptual boundaries firmly erected by private international and public lawyers. Against this background, TL illuminates the degree to which issues of jurisdiction flow from state-based understandings of jurisdictional competence. However, the conflict of laws that purportedly confronts the respective courts refusing to hear these cases can no longer be confined to territorial borders; increasingly, the norms governing the human rights claims are of such border-transgressing nature that they both undercut and surpass the territorial boundaries upon which various jurisdictional competences have been predicated up to this point. While this observation applies naturally to the universally binding norms of international law (regardless of whether or not states have transposed these obligations into their domestic legal regimes), cases involving civil suits against states, present and former state officials and corporations do not (yet) build on binding international law. Clearly, the general openness and receptiveness of domestic courts towards international law becomes a prime issue in ascertaining the prospects of cases for human rights abuses committed on foreign soil (Scott 2001; Brunnée/Toope, 2000-2001; Zumbansen, 2005; Flomo v. Firestone Nat. Rubber Co., LLC, 643 F.3d 1013 (7 $7^{\text {th }}$ Cir. 2011)). TL would suggest an alternative interpretation of the process whereby domestic courts appraise distant human rights abuses and the need to grant legal standing to the victims. Simultaneously, this re-interpretation requires a nuanced apprehension of the relevant norms that courts will have to draw upon in order to resolve these cases (Scott 2001; Wai, 2001; Keitner, 2008; Wuerth, 2010). TL offers itself as a means to capture the ambiguous dream of transnational civil human rights litigation in its widest sense. No one can deny that there are more problematic aspects to such human rights litigation than issues of procedural or substantive law. Through an increasingly widespread discussion, concern and awareness of distant rights abuses, transnational human rights litigation is preceded and fueled by a global scandalization of human rights abuses (Fischer-Lescano, 2002).

\section{IX.}

Transnational (Legal) History and Societal Memory. Whether in the form of a "big bang" of military or political revolution, or the inchoate, spontaneous and increasingly socialmedia propelled ways of setting free dynamics of transition and transformation, of postconflict, post-apartheid, and post-war justice, these developments have given rise to a wide-ranging, ambitious and innovative research agenda around the world that is concerned with the chances of a new "beginnings" and the need not only to adequately account for legacies and past experiences in the process (Teitel, 2000; Nagy, 2008), but to conceptualize and imagine the future as well. From post-apartheid South Africa, the Eastand West-German narratives of the Nazi past to post-genocide Rwanda, the ongoing nationbuilding in Iraq, Afghanistan, as well as the still unfolding consequences of the 'Arab Spring' 
in Eygpt. Syria or Lybia, the existing accounts of this process challenge our understanding of how to go about the future while minding the past.

Such fragile and vulnerable societal projects put enormous pressure on the law, torn between its association with a admonished and overcome system and its potential to provide a platform for future reconciliation, state building and societal integration. In the context of and in exchange with other complementing disciplines, TL reveals the distinct quality of fertilizing other conceptual searches while being informed by the transformations occurring within these disciplines (McEvoy, 2007). Despite its own riveted history, its contingencies and utopian aspirations, law itself reaches out to disciplines such as history, cultural studies and anthropology to tell its own story. With legal history emerging as a transnational enterprise (Merry, 1992; Anghie, 2005), such valuable undertakings can build on and learn from the work being done by historians and cultural studies scholars. The emergence of transnational history (Conrad/Osterhammel, 2004) gives overwhelming testimony of the border-crossing inquiry into the legitimation narratives of state and nation building (Conrad/Osterhammel, 2004; Wimmer/Feinstein, 2010). Formerly conceived and framed in discrete fashions, domestic/national historical narratives are discovered as sharing and being informed by experiences and semantic appropriations in comparative, transnational and global perspectives (Bright/Geyer, 1995; Bentley, 1996; Middell, 2000; Conrad/Osterhammel, 2004; Geschichte-transnational, ). This research bears large potential for concurrent explorations in work done in transnational legal history and TL in general (Hay/Craven, 2004).

\section{$\mathbf{X}$.}

Transnational Legal Education. The preceding sections demonstrated the degree to which transnational human rights litigation, transjudicial communications and constitutional 'borrowing' (Slaughter 2004), 'constitutional analogies' (Helfer, 2003) and the 'proliferation of international judicial bodies' (Romano, 1999) have long ceased to be of concern only to those working in international law. Any assessment of current developments in core fields of a law school curriculum will inevitably be informed by 'outside' influences of international, transnational and comparative law. While this insight is beginning to take hold in curriculum reform committees everywhere, there still remains a long way to bridge the gap between the mostly traditional canon of First Year Courses and the crème de la crème curriculum specializations restricted to Upper Year programs. While the struggle for democratic access to higher education still continues today (Boyd, 2005), change has long been coming with respect to the demographic and territorial transformation of today's student (and faculty) bodies. With prospective students likely to be more mobile and de-territorialized in their selection of higher education institutions, the same is suggested to them with respect to employment opportunities after graduation. In this light, the questions regarding the direction and content of curricula might have progressed, matured and changed to reflect a higher degree of the Law School's nervousness and responsiveness to the 'needs of the market' (Arthurs, 2000), while the 
prospects of a rewarding employment are turning dimmer and dimmer (Standing, 2011). And yet, today's often frantic attempts to adapt the University to market demands also speak of a lack of self-reflection, reconsideration and wider-scale assessment of the conditions, role and function of education and learning as such (Macdonald/MacLean, 2005; Macdonald, 1990; Leibfried/Möllers/Schmid/Zumbansen, 2006; Dedek/de Mestral, 2009). With national traditions and trajectories proving to be very influential in shaping future conceptual thinking about education and university reform, the need arises to bring make visible and engage these distinct, nationalized or segregated discourses in a global context (Koskenniemi, 2007). Focusing on legal theory from the perspective of the 'political economy of (legal) education', the formation and training of lawyers becomes a crucial inquiry into the democratic accessibility of university studies, into the training of elites, and into questions of power and exclusion, of identity and of finding - oneself - again (Goodrich, 1996; Arthurs, 2002).

This dialectical process is painfully felt throughout one's academic career. The ambiguity of technical terms, legal concepts and principles coincides with the daily challenge to position oneself and one's work (Wiethölter, 1968: 168; Wiethölter, 1965; Kennedy, 2004). This anxiety is particularly prevalent where academic research, writing and teaching is so intertwined with real politics (Arthurs, 2002; Weiss, 2003). The open-endedness of categories such as labour law, economic law, social law, and 'public' and 'private' law can go some way in laying bare national traditions, idiosyncrasies and blind spots of legal cultures; in turn, these traditions are themselves intertwined, non-linear, disputed and contested. And, of course, how could this not be otherwise? (Glenn, 2004; Glenn, 2005). It is the constant challenge of the researcher and the teacher to work in the light of this complex history in order to carefully help shape the future. In particular in light of an undeniably growing pressure to include a decisive focus on practice, experiential and clinical work in today's legal education, questions regarding foundations and content are perhaps even more crucial than ever. Attempts to address such questions, however, have to take the transnational context into account, in which law operates (Scott, 2005; Aman Jr./Zumbansen, 2012). It seems, we are - yet again - just at the beginning. 


\section{References}

Aman Jr., A. \& Zumbansen, P. 2012. Transnational Law: Actors, Norms, Processes. Charlottesville, NC: Lexis Nexis (Forthcoming)

Aman Jr., A. C. 1997. Administrative Law for a New Century. In M. Taggart (ed) The Province of Administrative Law. Oxford/Portland, OR: Hart Publishing, 90-107

Aman Jr., A. C. 2004. The Democracy Deficit. New York: New York University Press

Anders, G., 2008. The Normativity of Numbers: World Bank and IMF Conditionality. PoLAR: Political and Legal Anthropology Review 31: 187-202

Anghie, A. 2005. Imperialism, Sovereignty and the Making of International Law. Cambridge: Cambridge University Press

Appadurai, A., 1990. Disjuncture and Difference in the Global and Cultural Economy. Public Culture 2: 1-24

Arbour, L. \& Lafontaine, F., 2007. Beyond Self-Congratulation: The Charter at 25 in an International Perspective. Osgoode Hall Law Journal 45: 239-275

Arthurs, H. W. 1988. Without the Law: Administrative Justice and Legal Pluralism in Nineteenth Century England. Toronto: University of Toronto Press

Arthurs, H. W., 2000. Poor Canadian Legal Education: So Near to Wall Street, So Far from God. Osgoode Hall Law Journal 38: 381-408

Arthurs, H. W., 2002. National Traditions in Labor Law Scholarship: The Canadian Case. Comparative Labor Law \& Policy Journal 23: 645-678

Arthurs, H. W. 2002. Private Ordering and Workers' Rights in the Global Economy: Corporate Codes of Conduct as a Regime of Labour Market Regulation. In J. Conaghan, R. M. Fischl \& K. Klare (eds), Labour Law in an Era of Globalization. Transformative Practices and Possibilities. Oxford/New York: Oxford University Press, 471-487

Arthurs, H. W., 2002. The State We're In: Legal Education in Canada's new Political Economy. Windsor Yearbook of Access to Justice 27: 35-54

Backer, L. C., 2011. Private Governance, Soft Law, and the Construction of Polycentric Networks for the Regulation of Transnational Corporations. Indiana Journal of Global Legal Studies 17: forthcoming

Barr, M. S. \& Miller, G. P., 2006. Global Administrative Law: The View from Basel. European Journal of International Law 17: 15-46

Baxi, U. 2003. Global Development and Impoverishment. In P. Cane \& M. Tushnet (eds), The Oxford Handbook of Legal Studies. Oxford/New York: Oxford University Press, 455-482

Bentley, J. H., 1996. Cross-Cultural Interaction and Periodization in World History. American Historical Review 101: 749-770

Berger, K.-P. 2010. The Creeping Codification of the New Lex Mercatoria. Second Edition. Alphen aan den Rijn, NL: Wolters Kluwer

Berger, K. P. 1996. Formalisierte oder 'schleichende' Kodifizierung des transnationalen Wirtschaftsrechts: zu den methodischen und praktischen Grundlagen der lex mercatoria. Berlin/New York: Walter de Gruyter

Berman, P. S., 2005. From International Law to Law and Globalization. Columbia Journal of Transnational Law 43: 485-556

Bogdandy, A., Dann, P. \& Goldmann, M., 2008. Developing the Publicness of Public International Law. German Law Journal 9: 1375-1400

Boyd, S., 2005. Corporatism and Legal Education in Canada. Social \& Legal Studies 14: 287-297

Boyer, R. \& Hollingsworth, J. R. 1997. From National Embeddedness to Spatial and Institutional Nestedness. In J. R. Hollingsworth \& R. Boyer (eds), Contemporary Capitalism. The Embeddedness of Institutions. Cambridge: Cambridge University Press, 433-484

Bozeman, A. B. 1971. The Future of Law in a Multicultural World. Princeton, NJ: Princeton University Press

Bratton, W. W., 2005. Welfare, Dialectic, and Mediation in Corporate Law. Berkeley Business Law Journal 2: $59-76$

Bright, C. \& Geyer, M., 1995. World History in a Global Age. American Historical Review 100: 1034-1060 
Brunkhorst, H. 2010. Constitutionalism and Democracy in the World Society. In P. Dobner \& M. Loughlin (eds), The Twilight of Constitutionalism? Cambridge: Cambridge University Press, 179-198

Brunnée, J., 2004. Of Sense and Sensibility: Reflections on International Liability Regimes as Tools for Environmental Protection. International and Comparative Law Quarterly 53: 351-367

Brunnée, J. \& Toope, S., 2000-2001. International Law and Constructivism: Elements of an Interactional Theory of International Law. Columbia Journal of Transnational Law 39: 19

Brunsson, N. \& Jacobsson, B. 2000. A World of Standards. Oxford/New York: Oxford University Press

Buxbaum, H., 2004. National Courts, Global Cartels. German Law Journal 5: 1095-1106

Buxbaum, H. L., 2010. National Jurisdiction and Global Business Networks. Indiana Journal of Global Legal Studies 17: 165-181

Calliess, G.-P., 2002. Reflexive Transnational Law. The Privatisation of Civil Law and the Civilisation of Private Law. Zeitschrift für Rechtssoziologie 23: 185-216

Calliess, G.-P., 2007. The Making of Transnational Contract Law. Indiana Journal of Global Legal Studies 14: 469-483

Calliess, G.-P. \& Zumbansen, P. 2010. Rough Consensus and Running Code: A Theory of Transnational Private Law. Oxford, UK: Hart Publishing

Chimni, B. S., 2005. Co-option and Resistance: Two Faces of Global Administrative Law. New York University Journal of International Law \& Politics 37: 799-827

Choudhry, S. (ed) The Migration of Constitutional Ideas (Cambridge University Press, 2006)

Conrad, S. \& Osterhammel, J. (eds), Das Kaiserreich transnational. Deutschland in der Welt 1871 - 1914 2004)

Cordes, A., 2003. The Search for a Medieval Lex Mercatoria. Oxford University Comparative Law Forum 5: http://ouclf.iuscomp.org/articles/cordes.shtml

Cotterrell, R., 2008. Transnational Communities and the Concept of Law. Ratio Juris 21: 1-18

Cover, R. M., 1983. Nomos and Narrative. Harvard Law Review 97: 4-68

Cranston, R., 2007. Theorizing Transnational Commercial Law. Texas International Law Journal 42: 597-617

de Bellis, M., 2006. Global Standards for Domestic Financial Regulations: Concourse, Competition and Mutual Reinforcement between Different Types of Global Administration. Global Jurist Advances 6: Article 6

Dedek, H. \& de Mestral, A., 2009. 'Born to be Wild': The 'Trans-systemic' Programme at McGill and the DeNationalization of Legal Education. German Law Journal 10: 889-911

Djelic, M.-L. \& Sahlin, K. 2012. Reordering the World: Transnational Regulatory Governance and Its Challenges. In D. Levi-Faur (ed) Oxford Handbook on Governance. Oxford: Oxford University Press, 745-758

Dobner, P. 2010. More Law, less Democracy? Democracy and Transnational Constitutionalism. In P. Dobner \& M. Loughlin (eds), The Twilight of Constitutionalism? Cambridge: Cambridge University Press, 141161

Dorsen, N., Rosenfeld, M., Sajó, A. \& Baer, S. 2010. Comparative Constitutionalism. Cases and Materials. 2nd ed. St Paul, MN: West

Drache, D. \& Boyer, R. (eds), States Against Markets: The Limits of Globalization (Routledge, 1996)

Drezner, D. W. 2007. All Politics is Global. Explaining International Regulatory Regimes. Princeton \& Oxford: Princeton University Press

Dunoff, J. L. \& Trachtman, J. P. (eds), Ruling the World?'Constitutionalism, International Law, and Global Governance (Cambridge University Press, 2009)

Ehrlich, E. 1962. Fundamental Principles of the Sociology of Law (orig. published in German as Grundlegung der Soziologie des Rechts, 1913). New York: Russell \& Russell

Fischer-Lescano, A., 2002. Globalverfassung, Verfassung der Weltgesellschaft. Archiv für Rechts- und Sozialphilosophie [ARSP] 88: 349-378

Fischer-Lescano, A. \& Teubner, G., 2004. Regime-Collisions: The Vain Search for Legal Unity in the Fragmentation of Global Law. Michigan Journal of International Law 25: 999-1046

Forsthoff, E. 2000. The Administration as Provider of Services (transl. from Der Staat der Daseinsvorsorge, 1938). In A. J. Jacobson \& B. Schlink (eds), Weimar. A Jurisprudence in Crisis. Berkeley: University of California Press, 326-327

Frankenberg, G. 1996. Shifting Boundaries: The Private, the Public, and the Welfare State. In M. B. Katz \& C. Sachße (eds), The Mixed Economy of Social Welfare. Baden-Baden: Nomos, 72-94

Freeman, J., 2000. The Contracting State. Florida State University Law Review 28: 155-214 
Friedmann, W., Henkin, L. \& Lissitzyn, 0. (eds), Transnational Law in a Changing Society. Essays in the Honor of Philip C. Jessup (Columbia University Press, 1972)

Frug, G., 1983. The Ideology of Bureaucracy in American Law. Harvard Law Review 97: 1277-1388

Gaillard, E. 2010. Legal Theory of International Arbitration. Leiden \& Boston: Martinus Nijhoff Publishers

Geschichte-transnational http://geschichte-transnational.clio-online.net/transnat.asp?lang=en.

Glenn, H. P. 2004. Legal Traditions of the World: Sustainable Diversity in Law [2000] 2nd ed. Oxford/New York: Oxford University Press

Glenn, H. P., 2005. Doin' the Transsystemic: Legal Systems and Legal Traditions. McGill Law Journal 50: 863898

Goldman, B., 1964. Frontières du droit et 'lex mercatoria'. Archives de la Philosophie de Droit 13: 177-192

Goode, R., 1997. Usage and Its Reception in Transnational Commercial Law. International and Comparative Law Quarterly 46: 1-36

Goodrich, P., 1996. Law and the Courts of Love: Andreas Capellanus And The Judgments Of Love. Stanford Law Review 48: 633-675

Granovetter, M., 1985. Economic Action and Social Structure: The Problem of Embeddedness. American Journal of Sociology 91: 481-510

Greenhouse, C., 2006. Fieldwork on Law. Annual Review of Law and Social Sciences 187-210

Grimm, D., 1980. Reformalisierung des Rechtsstaatsprinzips als Demokratiepostulat. Juristische Schulung [JuS] 20: 704

Habermas, J. 1996. Between Facts and Norms [transl. William Rehg]. Cambridge: MIT Press

Habermas, J. 2001. The Postnational Constellation. Cambridge, MA: MIT Press

Habermas, J. 2008. A Political Constitution for the Pluralist World Society? In J. Habermas (ed) Between Naturalism and Religion. Philosophical Essays. London: Polity, 312-352

Harlow, C. 1999. European Administrative Law and the Global Challenge. In P. Craig \& G. d. Búrca (eds), The Evolution of EU Law. Oxford/New York: Oxford University Press, 261-285

Harlow, C., 2006. Global Administrative Law: The Quest for Principles and Values. European Journal of International Law 17: 187-214

Harlow, C. 2009. The 'Hidden Paw' of the State and the Publicisation of Private Law. In D. Dyzenhaus, M. Hunt \& G. Huscroft (eds), A Simple Common Lawyer. Essays in Honour of Michael Taggart. Oxford, UK/Portland, OR: Hart Publishing, 75-97

Harvey, D., 2005. The Sociological and Geographical Imaginations. International Journal of Politics, Culture and Society 211-256

Hay, D. \& Craven, P. (eds), Masters, Servants, and Magistrates in Britain and the Empire, 1562-1955 (University of North Carolina Press, 2004)

Held, D. 2007. Reframing Global Governance: Apocalypse Soon or Reform! In D. Held \& A. McGrew (eds), Globalization Theory. Approaches and Controversies. London: Polity, 240-260

Held, D. \& McGrew, A. (eds), The Global Transformations Reader. An Introduction to the Globalization Debate (2000), 2nd ed. (Polity, 2003)

Helfer, L. R., 2003. Constitutional Analogies in the International Legal System. Loyola of Los Angeles Law Review 193-236

Herkenrath, M. 2003. Transnationale Konzerne im Weltsystem. Globale Unternehmen, nationale Wirtschaftspolitik und das Problem nachholender Entwicklung. Opladen: Westdeutscher Verlag

Hertner, P. 1998. Corporate Governance and Multinational Enterprise in Historical Perspective. In K. J. Hopt, H. Kanda, M. J. Roe, E. Wymeersch \& S. Prigge (eds), Comparative Corporate Governance - The State of the Art and Emerging Research. Oxford: Clarendon Press, 41-59

Hoffmann, F. F. 2008. In Quite a State: Trials and Tribulations of an Old Concept in New Times. In R. A. Miller \& R. Bratspies (eds), Progress in International Law. The Hague: Martin Nijhoff, 263-288

Holmes, D. R. \& Marcus, G. E. 2005. Cultures of Expertise and the Management of Globalization: Toward the Refunctioning of Ethnography. In A. Ong \& S. J. Collier (eds), Global Assemblages: Technology, Politics, and Ethics as Anthropological Problems. Oxford: Blackwell, 235-252

Holmes, 0. W. J., 1897. The Path of the Law. Harvard Law Review 10: 457 
Hopt, K. J. 2006. Comparative Company Law. In M. Reimann \& R. Zimmermann (eds), Oxford Handbook of Comparative Law. Oxford/New York: Oxford University Press, 1161-1191

Jacoby, S. M. 2004. The Embedded Corporation. Corporate Governance and Employment Relations in Japan and the United States. Princeton and Oxford: Princeton University Press

Jessup, P. C. 1956. Transnational Law. New Haven: Yale University Press

Joerges, C. 1972. Zum Funktionswandel des Kollisionsrechts. Die 'Governmental Interest Analysis' und die 'Krise des Internationalen Privatrechts'. Berlin/Tübingen: Walter de Gruyter/Siebeck Mohr

Joerges, C., 2004. The Challenges of Europeanization in the Realm of Private Law: A Plea for a New Legal Discipline. Duke Journal of Comparative \& International Law 14: 149-196

Keitner, C. I., 2008. Conceptualizing Complicity in Alien Tort Cases. Hastings Law Journal 60: 61-104

Kennedy, D., 1997. New Approaches to Comparative Law: Comparativism and International Governance. Utah Law Review 545-637

Kennedy, D. 2004. Legal Education and the Reproduction of Hierarchy. A Polemic against the System. New York: New York University Press

Kennedy, D., 2005. Challenging Expert Rule: The Politics of Global Governance. Sydney Law Review 27: 1-24

Kester, W. C. 1997. Governance, Contracting, and Investment Horizons: A Look at Japan and Germany. In D. H. Chew (ed) Studies in International Corporate Finance and Governance Systems. A Comparison of the U.S., Japan and Europe. New York/Oxford: Oxford University Press, 227-242

Kingsbury, B., Krisch, N. \& Stewart, R., 2005. The Emergence of Global Administrative Law. Law \& Contemporary Problems 68: 15-61

Kingsbury, B., Krisch, N., Stewart, R. B. \& Wiener, J., 2005. Global Governance as Administration--National And Transnational Approaches to Global Administrative Law. Law \& Contemporary Problems 68: 1-13

Knop, K., Michaels, R. \& Riles, A., 2008. Transdisciplinary Conflict of Laws: Introduction. Law \& Contemporary Problems 71: 1-17

Koskenniemi, M. 2002. The Gentle Civilizer of Nations: The Rise and Fall of International Law 1870-1960 (Hersch Lauterpacht Memorial Lectures). Cambridge: Cambridge University Press

Koskenniemi, M., 2007. International Law: Constitutionalism, Managerialism and the Ethos of Legal Education. Eur. J. Leg. Ed. 1: 1-18

Kreide, R., 2009. The Ambivalence of Juridification. On Legitimate Governance in the International Context. Global Justice: Theory Practice Rhetoric 2: 18-34

Krisch, N., 2009. Global Administrative Law and the Constitutional Ambition. LSE Law, Society and Economy Working Papers 10/2009, reprinted in Dobner/Loughlin eds., The Twilight of Transnational Constitutionalism? [Cambridge University Press, 2010, 245-266] http://ssrn.com/abstract=1344788

Krisch, N. 2010. Beyond Constitutionalism. The Pluralist Structure of Post-national law. Oxford/New York: Oxford University Press

La Forest, G. V., 1996. The Expanding Role of the Supreme Court of Canada in International Law Issues. Canadian Yearbook of International Law 34: 89

Ladeur, K.-H., 1997. Towards a Legal Theory of Supranationality - The Viability of the Network Concept. European Law Journal 3: 33-54

Ladeur, K.-H., 2011. The Evolution of General Administrative Law and the Emergence of Postmodern Administrative Law. Osgoode Hall Law School CLPE Research Paper Series 6: SSRN

Landis, J. W. 1938. The Administrative Process. New Haven: Yale University Press

Leibfried, S., Möllers, C., Schmid, C. \& Zumbansen, P., 2006. Redefining the Traditional Pillars of German Legal Studies and Setting the Stage for Contemporary Interdisciplinary Research. German Law Journal 7: 661-680

Levi-Faur, D., 2005. The Global Diffusion of Regulatory Capitalism. The Annals of The American Academy of Political and Social Science 598: 12-29

Luhmann, N., 1982. The World Society as a Social System. International Journal of General Systems 8: 131-138

Luhmann, N. 1985. A Sociological Theory of Law. London: Routledge Kegan \& Paul

Luhmann, N., 1995. Metamorphosen des Staates. in: Luhmann, Gesellschaftsstruktur und Semantik. Studien zur Wissenssoziologie der modernen Gesellschaft 101-137

Macaulay, S., 2000. Relational Contracts Floating on a Sea of Custom? Thoughts about the Ideas of Ian Macneil and Lisa Bernstein. Northwestern University Law Review 94: 775-804

Macdonald, R. A., 1990. The National Law Programme at McGill: Origins, Establishment, Prospects. Dalhousie Law Journal 13: 211 
Macdonald, R. A. \& MacLean, J., 2005. No Toilets in Park. McGill Law Journal forthcoming

Marks, S. 2000. The Riddle of All Constitutions. International Law, Democracy, and the Critique of Ideology. Oxford, UK/New York, NY: Oxford University Press

Marks, S., 2005. Naming Global Administrative Law. New York University Journal of International Law and Politics 37: 995-1001

McAdams, R. H., 1997. The Origin, Development, and Regulation of Norms. Michigan Law Review 96: 338-433

McEvoy, K., 2007. Beyond Legalism: Towards a Thicker Understanding of Transitional Justice. J. Law \& Soc. 34: 411-440

Merry, S. E., 1992. Anthropology, Law, and Transnational Processes. Annual Review of Anthropology 21: 357379

Merry, S. E., 2006. New Legal Realism and the Ethnography of Transnational Law. Law \& Social Inquiry 31: 975-995

Merry, S. E. 2012. Measuring the World: Indicators, Human Rights, and Global Governance. In P. Zumbansen \& R. Buchanan (eds), Law in Transition: RIghts, Development and Transitional Justice. Oxford \& Portland: Hart Publishing, forthcoming

Mertens, H.-J. 1997. Lex Mercatoria: A Self-applying System Beyond National Law? In G. Teubner (ed) Global Law Without A State. Dartmouth: Aldershot, 31-43

Meyer, J. W., Boli, J., Thomas, G. M. \& Ramirez, F. O., 1997. World Society and the Nation-State. American Journal of Sociology 103: 144-181

Michaels, R. 2004. Territorial Jurisdiction after Territoriality. In J. P. Slot \& M. Bulterman (eds), Globalisation and Jurisdiction. The Hague: Kluwer Law International, 105-130

Middell, M., 2000. Kulturtransfer und Historische Komparatistik - Thesen zu ihrem Verhältnis. Comparativ 10: 7-41

Milgrom, P. R., North, D. C. \& Weingast, B. W., 1990. The Role of Institutions in the Revival of Trade: The Law Merchant, Private Judges and the Champagne Fairs. Econ. \& Pol. 2: 1-23

Miller, R. A. \& Zumbansen, P. (eds), Comparative Law as Transnational Law: A Decade of the German Law Journal (Oxford University Press, 2012)

Moore, S. F., 1973. Law and Social Change: the semi-autonomous field as an appropriate subject of study. Law \& Society Review 7: 719-746

Nagy, R., 2008. Transitional Justice as Global Project: critical reflections. Third World Quarterly 29: 275-289

Neuborne, B., 2002. Preliminary Reflections on Aspects of Holocaust-Era Litigation in American Courts. Washington University Law Quarterly 80: 795-834

Nollkaemper, A. \& Nijman, J. (eds), New Perspectives on the Divide Between National and International Law (Oxford University Press, 2007)

Okafor, 0. C., 2008. Critical Third World Approaches to International Law (TWAIL): Theory, Methodology, or Both? International Community Law Review 10: 371-378

Peters, A., 2009. The Merits of Global Constitutionalism. Indiana Journal of Global Legal Studies 16: 397-411

Polanyi, K. 1944. The Great Transformation. The Political and Economic Origins of our Time. Boston: Beacon Press

Posner, E. A. 2000. Law and Social Norms. Cambridge, MA \& London, UK: Harvard University Press

Posner, R. A., 1997. The Path Away from the Law. Harvard Law Review 110: 1039-1043

Riles, A., 2005. A New Agenda for the Cultural Study of Law: Taking on the Technicalities. Buffalo Law Review 53: 973

Riles, A., 2006. Anthropology, Human Rights, and Legal Knowledge: Culture in the Iron Cage. American Anthropologist 108: 52-65

Rittich, K., 2005. Functionalism and Formalism: Their latest Incarnations in Contemporary Development and Governance Debates. University of Toronto Law Journal 55: 853-868

Rodrik, D. 2000. Governance of Economic Globalization. In J. S. Nye \& J. D. Donahue (eds), Governance in a Globalizing World. Washington, D.C.: Brookings, 347-365

Romano, C. P. R., 1999. The Proliferation of International Judicial Bodies: The Pieces of the Puzzle. New York University Journal of International Law and Policy 31: 709-751 
Said, E. W. 1978. Orientalism. New York: Vintage Books

Salter, L. 1999. The Standards Regime for Communication and Information Technologies. In A. C. Cutler, V. Haufler \& T. Porter (eds), Private Authority and International Affairs. Albany, NY: State University of New York Press, 97-127

Santos, A. 2006. The World Bank's Uses of the 'Rule of Law' Promise in Economic Development. In D. Trubek \& A. Santos (eds), The New Law and Economic Development. A Critical Appraisal. Cambridge: Cambridge University Press, 253-300

Sarfaty, G. A. 2012. Values in Translation: Human Rights and the Culture of the World Bank. Stanford: Stanford University Press

Sassen, S., 2000. The State and Economic Globalization: Any Implications for International Law? Chicago Journal of International Law 1: 109-116

Schachter, 0., 1986. Philip Jessup's Life And Ideas. American Journal of International Law (A.J.I.L.) 80: 878895

Schanze, E. 1986. Investitionsverträge im internationalen Wirtschaftsrecht. Frankfurt: Metzner

Schepel, H. 2004. Constituting Private Governance Regimes: Standards Bodies in American Law. In C. Joerges, I.-J. Sand \& G. Teubner (eds), Transnational Governance and Constitutionalism. Oxford/Portland, OR: Hart Publishing, 161-188

Schmitthoff, C. M., 1961. International Business Law: A New Law Merchant. Current Law and Social Problems 2: $129-153$

Schmitthoff, C. M., 1964. Das neue Recht des Welthandels. RabelsZ 28: 47

Schneiderman, D., 2000. Investment Rules and the New Constitutionalism. Law \& Soc Inquiry 25: 757-783

Schneiderman, D., 2006. Transnational Legality and the Immobilization of Local Agency. Annual Review of Law and Social Sciences 2: 387-408

Scott, C., 2005. A Core Curriculum for the Transnational Legal Education of JD and LLB Students: Surveying the Approach of the International, Comparative and Transnational Law Program at Osgoode Hall Law School. Penn State International Law Review 23: 757-773

Scott, C., 2008. Regulating Everything. Inaugural Lecture, University College Dublin, School of Law, 26.2.2008 http://geary.ucd.ie/mapping/images/Documents/RegEverything.pdf

Scott, C. M. 2001. Introduction to Torture as Tort: From Sudan to Canada to Somalia. In C. M. Scott (ed) Torture as Tort. Portland, OR/Oxford: Hart Publishing, 3-44

Sen, A. 1999. Development as Freedom. Oxford/New York: Oxford University Press

Shaffer, G. \& Nourse, V., 2009. Varieties of New Legal Realism: Can A New World Order Prompt A New Legal Theory? Cornell Law Review 61: 61-137

Shaffer, G. \& Pollack, M. A., 2009. Hard vs. Soft Law: Alternatives, Complements and Antagonists in International Governance. University of Minnesota Legal Studies Research Paper No. 09-23 http://ssrn.com/abstract $=1426123$

Shalakany, A., 2001. Arbitration and the Third World: A Plea for Reassessing Bias Under the Spector of Neoliberalism. Harvard International Law Journal 41: 419-468

Shapiro, M., 2000. Administrative Law Unbounded: Reflections on Government and Governance. Indiana Journal of Global Studies 8: 369-377

Shonfield, A. 1965. Modern Capitalism. The Changing Balance of Public and Private Power. London/New York/Toronto: Oxford University Press

Slaughter, A.-M., 2000. Judicial Globalization. Virginia Journal of International Law 40: 1103-1124

Sousa Santos, B. d., 2002. The Processes of Globalisation. Eurozine http://www.eurozine.com/pdf/2002-0822-santos-en.pdf

Standing, G. 2011. The Precariat. The New Dangerous Class. London: Bloomsbury

Stephens, B., 2002. Translating Filártiga: A Comparative and International Law Analysis of Domestic Remedies for International Human Rights Violations. Yale Journal of International Law 27: 1-57

Stewart, R. B., 2003. Administrative Law in the Twenty-First Century. New York University Law Review 78: 437-460

Stichweh, R., 2008. Das Konzept der Weltgesellschaft: Genese und Strukturbildung eines globalen Gesellschaftssystems. Rechtstheorie Sonderheft Weltrecht (Martin Schulte \& Rudolf Stichweh eds.) 39: 329-355 
Stolleis, M. 2006. Entwicklungsstufen der Verwaltungsrechtswissenschaft. In W. Hoffmann-Riem, E. SchmidtAssmann \& A. Voßkuhle (eds), Grundlagen des Verwaltungsrechts. Band I: Methoden. Maßstäbe. Aufgaben. Organisation. München: C.H. Beck, 63-119

Storper, M. \& Salais, R. 1997. Worlds of Production. The Action Frameworks of the Economy. Cambridge, MA/London: Harvard University Press

Teitel, R. 2000. Transitional Justice. Oxford/New York: Oxford University Press

Teubner, G., 1997. Breaking Frames: The Global Interplay of Legal and Social Systems. American Journal of Comparative Law 45: 145-169

Teubner, G., 1997. The King's Many Bodies: The Self-Deconstruction of Law's Hierarchy. Law \& Society Review 31: 763-787

Teubner, G. 2010. Fragmented Foundations: Societal Constitutionalism beyond the Nation State. In P. Dobner \& M. Loughlin (eds), The Twilight of Constitutionalism? Cambridge: Cambridge University Press, 327341

Tietje, C., Brouder, A. \& Nowrot, K. 2006. Philip C. Jessup's Transnational Law Revisited (Essays in Transnational Law No.50/2006). Halle:

Tully, J., 2002. The Unfreedom of the Moderns in Comparison to Their Ideals of Constitutional Democracy. Modern Law Review 65: 204-228

Twining, W. 2000. Globalisation and Legal Theory. Evanston, IL: Northwestern University Press

van Harten, G. 2006. Investment Treaty Arbitration and Public Law. Oxford: Oxford University Press

Vincent-Jones, P. 2006. The New Public Contracting. Regulation, Responsiveness, Relationality. Oxford/New York: Oxford University Press

Wai, R., 2001. In the Name of the International: The Supreme Court of Canada and the Internationalist Transformation of Canadian Private International Law. The Canadian Yearbook of International Law 34: 117-209

Walker, N., 2010. Out of Place and Out of Time: Law's Fading Coordinates. Edinburgh Law Review 14: 13-46 (http://ssrn.com/abstract $=1367591$ )

Weber, M. 1967. On Law in Economy and Society (transl. from the German Wirtschaft und Gesellschaft, 2nd ed., 1925, by E.Shils and M.Rheinstein, edited/annotated by M.Rheinstein). New York: Simon Schuster

Weiss, M., 2003. The Future of Comparative Labor Law as an Academic Discipline and as a Practical Tool. Comparative Labor Law \& Policy Journal 25: 169-181

Whytock, C. A., 2008. Litigation, Arbitration, and the Transnational Shadow of the Law. Duke Journal of Comparative and International Law 18: 449-475

Whytock, C. A., 2008. Taking Causality Seriously in Comparative Constitutional Law: Insights from Comparative Politics and Comparative Political Economy. Loyola of Los Angeles Law Review 41: 629682

Wiener, A., 2007. Contested Meanings of Norms: A Research Framework. Comparative European Politics 5: 117

Wiener, A. 2011. Global Constitutionalism: Mapping an Emerging Field. Background paper for the Conference: Constitutionalism in a New Key?, Berlin 28-29 January 2011 (http://cosmopolis.wzb.eu/content/program/conkey Wiener Mapping-Field.pdf). Berlin:

Wiethölter, R. 1965. Die Position des Wirtschaftsrechts im sozialen Rechtsstaat. In H. Coing, H. Kronstein \& E.-J. Mestmäcker (eds), Wirtschaftsordnung und Rechtsordnung, Festschrift für Franz Böhm zum 70. Geburtstag. Tübingen: Siebeck Mohr, 41-62

Wiethölter, R. 1968. Rechtswissenschaft. Frankfurt: Fischer

Wiethölter, R. 1977. Begriffs- oder Interessenjurisprudenz - falsche Fronten im IPR und Wirtschaftsverfassungsrecht. In A. Lüderitz \& J. Schröder (eds), Internationales Privatrecht und Rechtsvergleichung im Ausgang des 20. Jahrhunderts. Frankfurt: Alfred Metzner Verlag, 213-263

Wiethölter, R. 1986. Materialization and Proceduralization in Modern Law. In G. Teubner (ed) Dilemmas of Law in the Welfare State. Berlin/New York: Walter de Gruyter, 221-249

Willke, H. 1999. The Contingency and Necessity of the State. In D. Baecker (ed) Problems of Form. Stanford: Stanford University Press, 142-154 
Wilson, R. A. 2006. Tyrannosaurus Lex: The Anthropology of Human Rights and Transnational Law. In M. Goodale \& S. E. Merry (eds), The Practice of Human Rights: Tracking Law Between the Global and the Local. Cambridge, UK: Cambridge University Press, 342-369

Wimmer, A. \& Feinstein, Y., 2010. The Rise of the Nation-State across the World, 1816-2001. American Sociological Review 75: 764-790

Wuerth, I., 2010. The Alien Tort Statute and Federal Common Law: A New Approach. Notre Dame Law Review 85: 1931

Young, E. A., 2007. The Constitution outside the Constitution. Yale Law Journal 117: 408-473

Zumbansen, P., 2002. Piercing the Legal Veil: Commercial Arbitration and Transnational Law. European Law Journal 8: 400-432

Zumbansen, P., 2002b. The Privatization of Corporate Law? Corporate Governance Codes and Commercial Self-Regulation. Juridikum 136-145

Zumbansen, P., 2005. Beyond Territoriality: The Case of Transnational Human Rights Litigation. ConWEB Paper $4 / 2005$ at http://www.qub.ac.uk/schools/SchoolofPoliticsInternationalStudiesandPhilosophy/Research/Paper Series/ConWEBPapers/

Zumbansen, P. 2006. Transnational Law. In J. Smits (ed) Encyclopedia of Comparative Law. Edward Elgar, $738-754$

Zumbansen, P., 2007. The Law of Society: Governance Through Contract. Indiana Journal of Global Legal Studies 14: 191-233 [available at http://ssrn.com/abstract=988610]

Zumbansen, P., 2008. Law After the Welfare State: Formalism, Functionalism and the Ironic Turn of Reflexive Law. American Journal of Comparative Law 56: 769-805

Zumbansen, P., 2010. Transnational Legal Pluralism. Transnational Legal Theory 1: 141-189 (http://ssrn.com/abstract=1542907)

Zumbansen, P., 2011. Neither 'Public' nor 'Private', 'National' nor 'International': Transnational Corporate Governance from a Legal Pluralist Perspective. Journal of Law \& Society 38: 50-75 